\title{
An application of the geophysical methods and ALS DTM for the identification of the geological structure in the Kraśnik region - Lublin Upland, Poland
}

\author{
Mirosław Kamiński ${ }^{1, *}$ \\ ${ }^{1}$ Polish Geological Institute - National Research Institute, Geological Mapping and Regional Geology \\ Program, 00-975 Warsaw, Poland
}

\begin{abstract}
The purpose of the study was the assessment of the viability of selected geophysical methods and the Airborne Laser Scanning (ALS) for the identification and interpretation of the geological structure. The studied area is covered with a dense forest. For this reason, the ALS numerical terrain model was applied for the analysis of the topography. Three geophysical methods were used: gravimetric, in the form of a semi-detailed gravimetric photograph, Vertical Electrical Sounding (VES), and Electrical Resistivity Tomography (ERT). The numerical terrain model enabled the identification of Jurassic limestone outcrops and interpretation of the directions of the faults network. The geological interpretation of the digitally processed gravimetric data enabled the determination of the spatial orientation of the synclines and anticlines axes and of the course directions of main faults. Vertical Electrical Sounding carried along the section line perpendicular to the Gościeradów anticline axis enabled the interpretation of the lithology of this structure and identification of its complex tectonic structure. The shallow geophysical surveys using the ERT method enabled the estimation of the thickness of Quaternary formations deposited unconformably on the highly eroded Jurassic limestone outcrop. The lithology of Quaternary, Cretaceous and Jurassic rocks was also interpreted.
\end{abstract}

\section{Introduction}

Recent years brought an increase in the practical implementation of modern geophysical and photogrammetric methods in geological charting [1]. Geophysical method are used for the identification and interpretation of geological structure while the photogrammetric methods are often used to analyse the topographic formations.

Among the photogrammetric methods, particular attention should be paid to the numeric terrain model (NTM) generated as a result of filtering a cloud of points received from Airborne Laser Scanning. The advantage of this model is detailed representation of the surface topography. The NTMs are generated only with points representing the surface. For this reason, ALS NTMs are particularly useful for the geomorphological surveying of limited

* Corresponding author: miroslaw.kaminski@pgi.gov.pl 
access areas and areas covered by vegetation and forests. The accuracy of the model depends on scanning density. For example, the ISOK project (IT system of the Country's Protection Against Extreme Hazards) uses the scanning density for non-urban areas of 4 points $/ \mathrm{m}^{2}$. Further computer analysis of this model enables appropriate NTM visualisation. It is possible to track the readability of lithology (resistance to weathering) and tectonic structure (determination of the positions of strata, course of faults and folds. This model is particularly useful for the interpretation of various geomorphological formations which is very important for geological charting. It enables the range and shape of river terraces, dunes, ravines and mass movements, particularly landslides $[1,2]$.

Other non-invasive geophysical method are also used in order to prepare the Detailed Geological Map of Poland in the 1:50,000 scale. Some of them are already included in the typical set of surveying methods in geological charting, others are just being introduced. Electrical resistivity sounding and profiling methods are among the more important. The Electrical Resistivity Tomography (ERT) method is less often used for geological charting.

The semi-detailed analysis of a gravimetric photograph is also used for geological surveying. The area of Poland is covered with such a photograph with a density of nearly 3 points per $\mathrm{km}^{2}$. Each point is provided with gravimetric data, geographical coordinates and elevation data. These data enable the creation of gravimetric and topographic maps. The use of gravimetry in geological charting is mostly based on the analysis of the maps of gravimetric anomalies and their qualitative interpretation. In effect, the information regarding the distribution of geological formations and courses of dislocation zones are obtained [3].

\section{Geomorphological and geological characteristics of the study area}

The area of the Kraśnik sheet of the DGMP (Detailed Geological Map of Poland) in the scale of 1:50,000 is located in the south-eastern part of Poland, within the Lublin Upland (Fig. 1). According to the physico-geographical division of Poland [4], the area of the sheet is located entirely within the Urzędów Heights. The Urzędów Heights comprise the south-western part of the Lublin Upland. They are an upland with levelled plateaus, cut with river valleys and ravines typical for loess areas. The most prominent feature of the topography is the long Wyżnica river valley with asymmetric slopes. The left slope, consisting of loess formations, is significantly higher and steeper. The right slope, consisting of Cretaceous formations, is more gentle and blends in with the topography. The elevation differences within the sheet area are relatively significant, upwards of $100 \mathrm{~m}$.

In terms of geology, the study area is located within the Radom-Kraśnik Palaeozoic elevation which forms a foundation for the SW wing of the Lublin basin [5]. The basin separates the rigid East-European platform from the fold structures of Western Europe. The Palaeozoic foundation is located at the depth from 1000 to $1500 \mathrm{~m}$. It consists of Devonian limestones and dolomites as well as Carboniferous mudstones, claystones and sandstones. Upper Jurassic formations are deposited unconformably on top of the foundation. Higher in the profile, there is a complex of Upper-Cretaceous carbonate rocks with the thickness of approx. 800-1000 m. Upper Cretaceous formations are represented by Cenomanian, Turonian, Coniacian, Santonian, Campanian and Maastrichtian deposits. In this area, Quaternary deposits are only partially preserved. The north-eastern part of the area is heavily denudated and devoid of these formations in many places. The south-western part is covered with a thick layer of loess (max. over $10 \mathrm{~m}$ ). Under the loess layer, there are Riss glaciation formations, i.e. glacial sands and gravels, residual sands with boulders and glacial tills. 


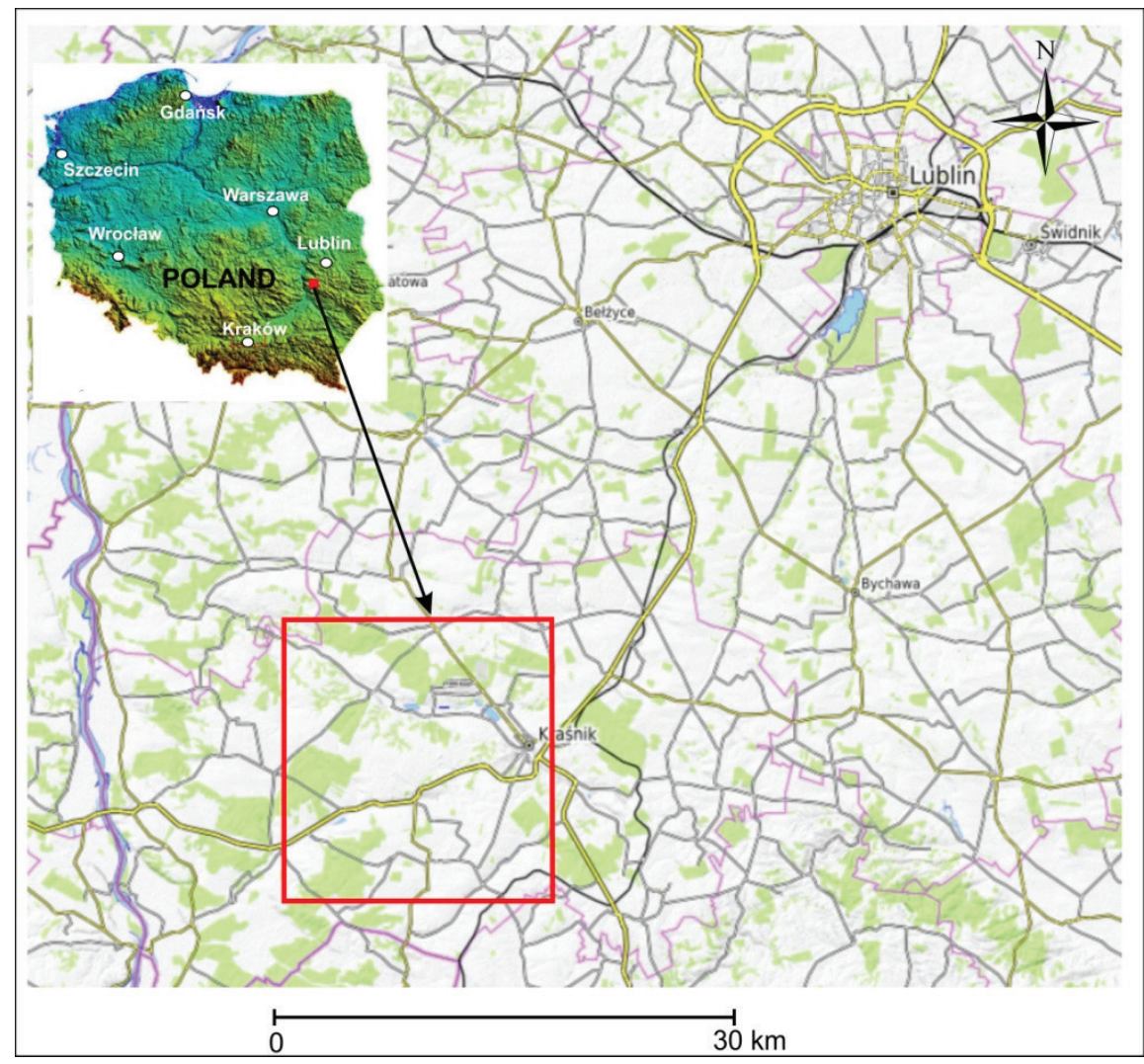

Fig.1. Location of the study area.

\section{Methodology}

\subsection{Gravimetry}

The gravimetric method analyses the changes in the intensity of the weight field which, in some simplification, correspond to the density variation of rocks forming the analysed rock medium [3]. The changes in the rock density value are a result of the lithological changes of the rock medium. The use of gravimetry in geological charting is mostly based on the analysis of the maps of gravimetric anomalies and their qualitative interpretation. In effect, the information regarding the distribution of geological formations and courses of dislocation zones are obtained. The primary map used for the analysis is the Bouguer anomaly map. The map of residual anomalies obtained by removing regional anomalies from the Bouguer anomaly map is more useful for the purposes of shallow geological charting. In this method we obtain a map of variation in the gravitational field in the zone from the surface to the depth determined as the function of the assumed averaging radius. For the DGMP Kraśnik sheet, the gravimetric maps were prepared using the Surfer v.11 software (Golden Software Inc.). The interpolation grids with the mesh size of $250 \times 250 \mathrm{~m}$ were calculated using kriging. The map of anomalies in the Bouguer reduction was calculated for the reduction density of $2.25 \mathrm{~g} / \mathrm{cm}^{3}$. The map of local anomalies was calculated using the Griffin method [6], assuming the averaging radius of $\mathrm{r}=1 \mathrm{~km}$. 


\subsection{Vertical Electric Sounding (VES)}

Vertical Electric Sounding (VES) involves measuring the electrical resistivity with varying distances of current electrodes from potential electrodes in consecutive measurement steps. As the distance between the electrodes is increased, the depth range of the measurement increases. The resulting chart presents the distribution of apparent electrical resistivity from the ground surface down [7]. The quantitative interpretation of the sounding involves the determination of the thickness and specific resistivity of geological strata [8]. The VES measurements were carried out using the Schlumberger symmetrical measurement system. The length of the power supply line to the measurement system was $A B / 2=250-320 \mathrm{~m}$, which provided the depth range of measurements of 130-150 m. The measurements were carried out using the direct current digital measurement instruments type ADG-7 powered by batteries with a direct current converter.

Sounding location and terrain morphology were determined based on GPS measurements and the topographic map in the scale of 1:25,000. The results of the measurements were presented on a geoelectrical section made in the horizontal scale of 1:20,000 and vertical scale of 1:2000. The section presents the location and distribution of the RoT resistivity values for each VES measurement profile. For some sections of the study area, the resistivity of near-surface layers reach tens of thousands of ohms. For this reason, it was decided to present the results in the form of logarithmic values, for better graphical representation of the resistivity values distribution. The resulting material of the field studies is the RoT electrical resistivity section presenting the RoT values to the depth of $200 \mathrm{~m}$.

\subsection{Electrical Resistivity Tomography (ERT)}

The Electrical Resistivity Tomography method provides continuous values of electrical resistivity along the measurement profile line due to the placement of a large number of measurement electrodes [9]. The electrodes are installed at even distances and connected by a multi-wire cable with a computer electrode selector and an electric meter. The electrode selector enables the connection of the meter to any combination of electrodes and measuring the apparent resistivity. Then, further measurements are taken according to the programmed procedure. It is possible to select any measurement system, e.g. Wenner, Dipole-Dipole or Schlumberger. The measured values of apparent resistivity are processed and visualised for purposes of qualitative and quantitative interpretation. The Res2DINV software by Geotomo Software was used to process the data and carry out the inversion.

As part of the field study, an ERT profile was prepared on the Kraśnik sheet in the Wenner measurement system with the length of $600 \mathrm{~m}$ and electrodes pitch of $5 \mathrm{~m}$. The maximum depth range was approx. $60 \mathrm{~m}$.

\subsection{ALS digital model}

The elevation data from the flood-prevention ISOK project were used for studying the topography. The products of the ISOK project are provided by the Geodesic and Cartographic Documentation Center in Warsaw (www.codgik.gov.pl). The data obtained during laser scanning are save in the form of ASPRS LAS files, called LAS (Laser File Format). The scanning density was 4 points per square metre. The primary processes for processing the points cloud provided by the ALS scan are classification and filtration [10]. Elevation data were acquired in September 2014. The NTM generation process involved the classification of the points cloud. The points cloud was divided into the following layers: surface, low vegetation, medium vegetation, high vegetation and buildings. Then, the tools available in the QCoharent software were applied to filter the points related to surface topography from 
the cloud. The next step was the interpolation of elevation points using the deterministic algorithm IDW (Inverse Distance Weight). The effect was a NTM with the grid mesh size of $0.5 \mathrm{~m}$.

\section{Results}

\subsection{Gravimetry}

The analysed area is located within the gravimetric image of the Lesser Poland Upland [11], with visible three smaller positive anomalies. The Kraśnik sheet is located on the border of the anomaly called the Lublin Upland or the Janów-Biłgoraj Anomaly and the local lowland internally dividing the Lesser Poland Upland [12]. The Bouguer anomaly map presents four positive and three negative anomalies. Comparing the results with the structural map of the Cretaceous floor [13], it was found that the positive anomalies correspond to the courses of anticlines while the negative anomalies are correlated with the courses of the synclines. As a result, four anticlines and three synclines are presented on the Kraśnik sheet of the DGMP (fig. 2). The map of residual anomalies was used to interpret the directions of the fault network. The spatial distribution of the faults network (fig. 6B) was interpreted based on the archival geological data $[14,15]$ and the analysis of density differences in residual anomalies. Three directions were identified. In the southern part of the sheet, the dominant directions are N-S and W-E, while in the northern part, the most common directions are NE-SW and NW-SE (Fig. 3).

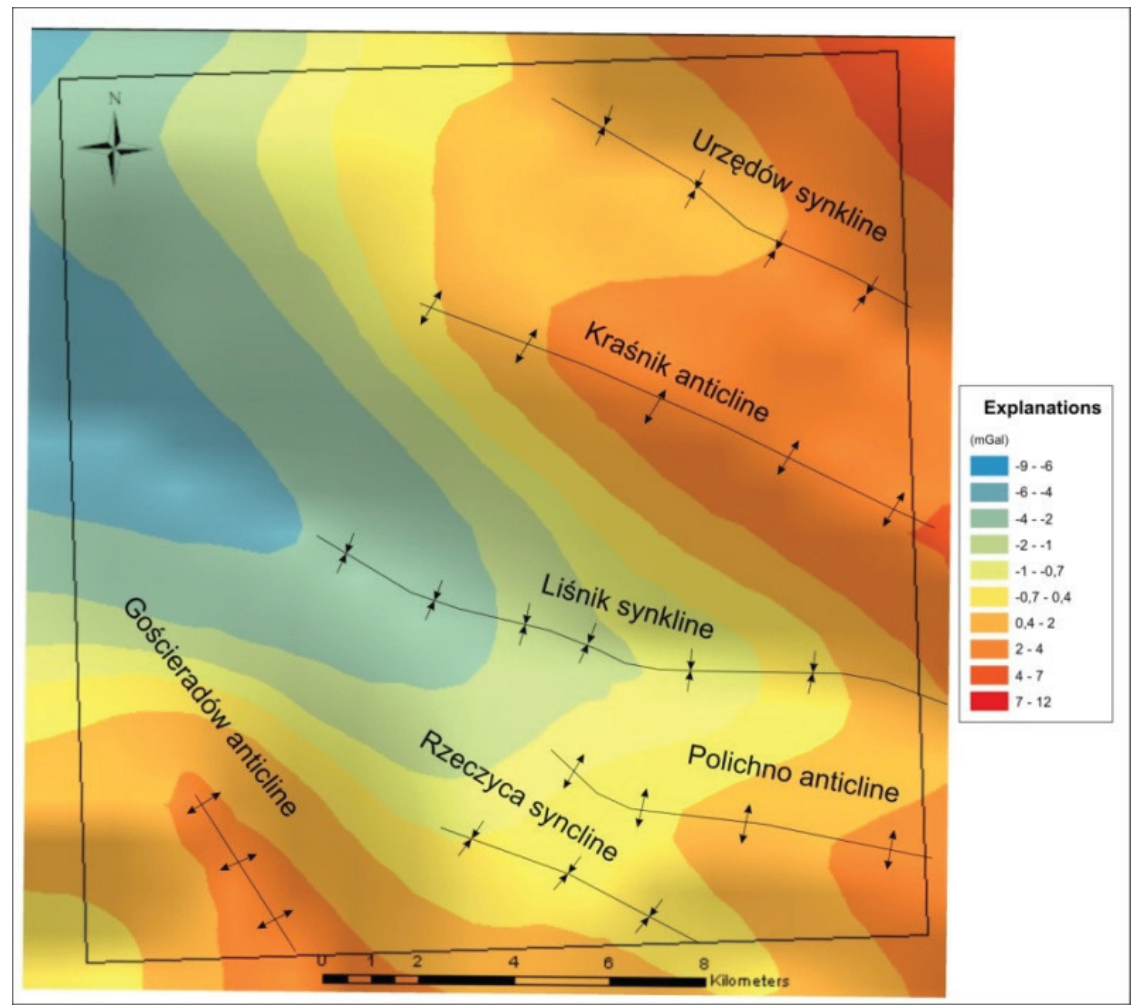

Fig. 2. The tectonic interpretation of the Bouguer anomaly. 


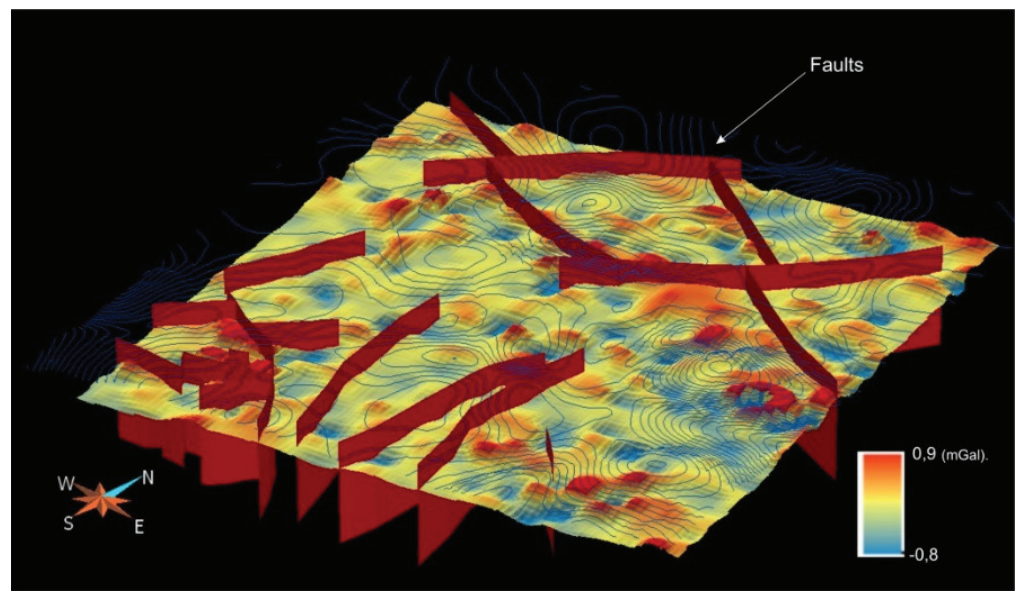

Fig. 3. The tectonic interpretation of residual anomalies.

\subsection{Vertical Electric Sounding (VES)}

The obtained RoT resistivity distribution image is a generalised image of the geological structure of the study area (Fig. 4). It is perpendicular to the axis of the Gościeradów anticline. This anticline was interpreted on the gravimetric anomalies image. Values from 2 to $2.8 \mathrm{ohm}$ are visible in the resistivity values distribution for the core of the anticline - they may correspond to limestone rocks. Jurassic limestones are shown on the surface between sounding 24 and 29. The core of the anticline is surrounded by rocks with the resistivity values from 1.7 to $2 \mathrm{ohm}$ on both sides. These are Cretaceous bedrocks. Stratigraphically younger marly bedrocks are deposited on the Cretaceous bedrocks from the NE side. Their resistivity values are within the range from 1.4 to $1.6 \mathrm{ohm}$. The shape of the anticline is asymmetric. It is cut with numerous faults which correlate with the faults interpreted from the residual gravimetric anomalies. Three regions with Quaternary formations were also determined on the Cretaceous formations. In the SW part of the section, there are highresistivity sands, with values up to $2.6 \mathrm{ohm}$. In the NE part, two areas with low-resistivity loess formations were identified. Their resistivity values are within the range from 1.5 to 1.7 ohm.

\subsection{Electrical Resistivity Tomography (ERT)}

The ERT profile was made perpendicularly to the axis of the Gościeradów anticline structure. The profile shows high-resistivity Quaternary formations which are deposited unconformably on Jurassic and Cretaceous formations. Three boreholes - S.24, s.25 and s.26 were used to validate the resistivity values on the ERT profile. In the NE part of the profile, the interpretation shows sandy loess on loam sands. The resistivity values of the sandy loess reach 218 to $330 \mathrm{ohm}$. Loam sands have the resistivity of 500-600 ohm. Loam sands further in the profile transform into high-resistance sands with the values reaching almost $900 \mathrm{ohm}$. The maximum thickness of these sands is approx. $28 \mathrm{~m}$ (Fig. 5). The entire surface of the roof of the anticline is heavily eroded. This is evidenced by the significant differences in the elevations of the roof surface for over-Quaternary formations. Jurassic formations are at the lowest depth of approx. $0.5 \mathrm{~m}$ in the SW part of the profile. Their deepest deposition is found in the NE part of the profile. Jurassic and Cretaceous formations include: limestones, marly dolomites, sandstones and bedrocks. They are not separated on the ERT profile due to the lack of data required for their validation. 


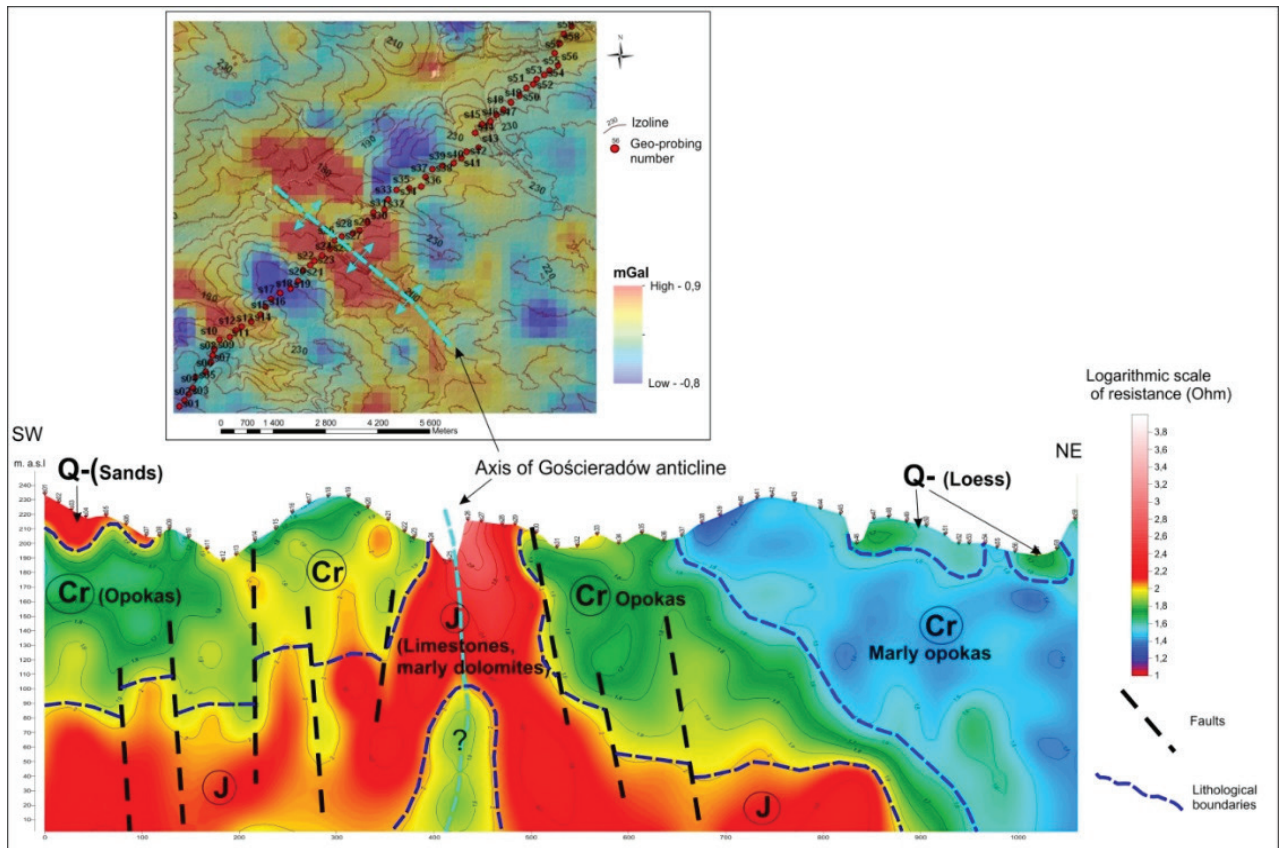

Fig. 4. Geological interpretation of the VES profile.

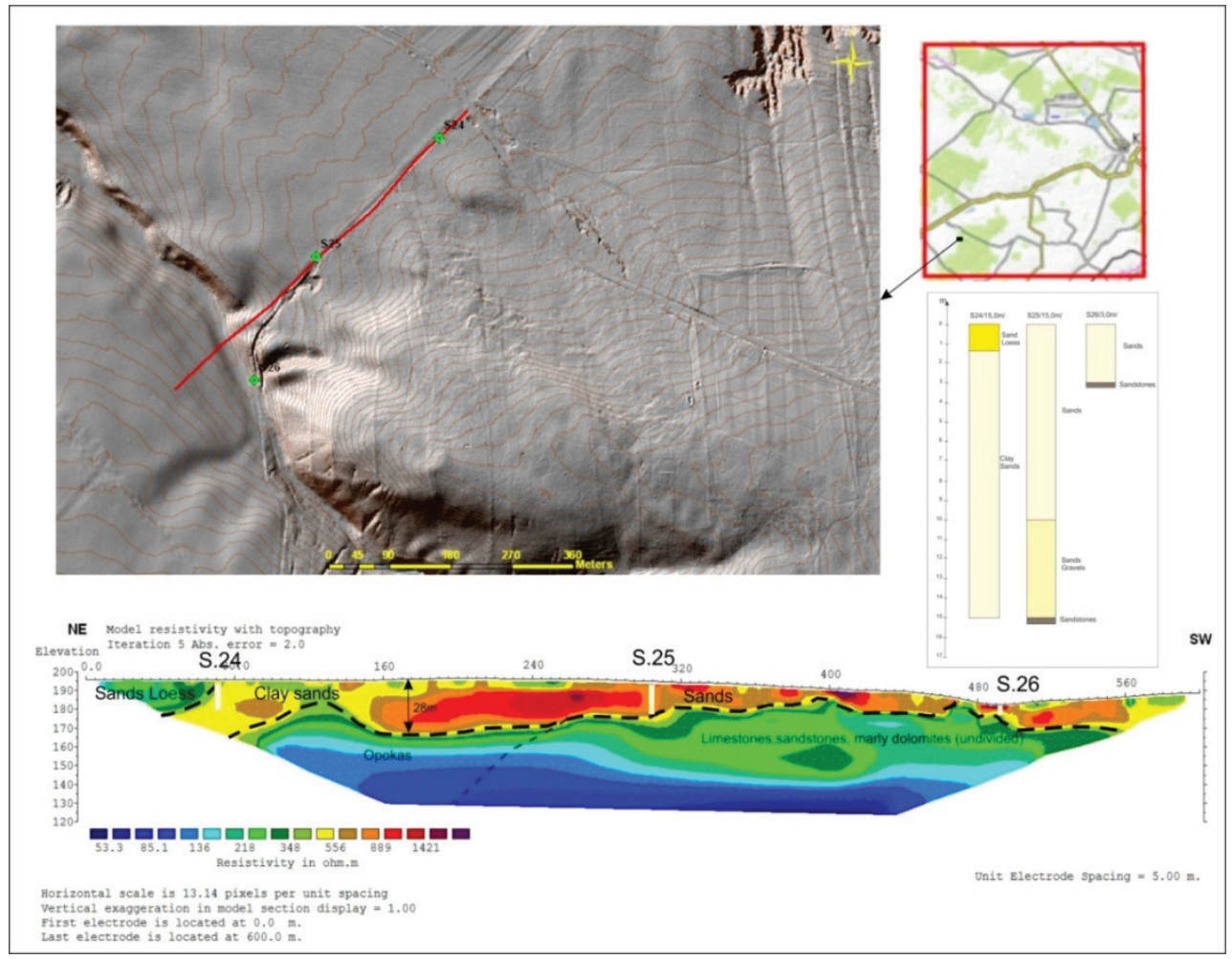

Fig. 5. Geological interpretation of the ERT profile. 


\subsection{ALS}

The part of the area with the Gościeradów anticline was selected for the purposes of geomorphological photographic interpretation. The lithological lines of Jurassic limestone outcrops cut with two fault networks were interpreted on the ALS digital terrain model (Fig. 6). The direction of the first system is SW-NE and of the second - SE-NW. Side wings of the anticline are not readable in the topography due to being covered with Quaternary deposits.

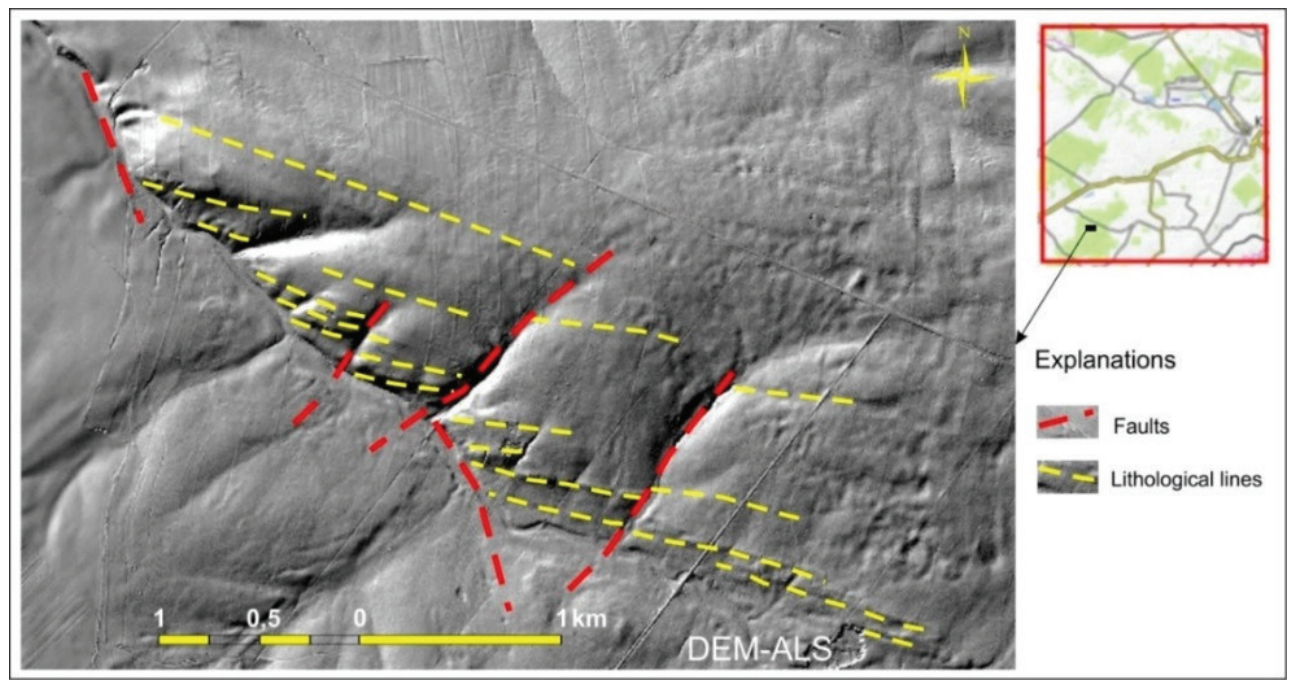

Fig. 6. Tectonic interpretation of the ALS model.

\section{Discussion}

The applied geophysical methods provided important information for the identification and interpretation of the geological structure of the study area. The ALS digital terrain model was also found to be useful - this type of information should be routinely used in geomorphological surveys.

As for the electrical resistivity methods, it should be noted that they have some limitations. They can be applied where there are relatively clear contrasts of electrical resistivity between adjacent geological formations. In the case of the VES method - its resolution decreases with depth. This is also true for the ERT - the resolution of the method decreases significantly at the depth of approx. 50 metres. It should be noted that the resolution of the Electrical Resistivity Tomography is however still much more precise than in the case of Vertical Electric Sounding. In the case of the Gościeradów anticline, it was evidenced by the fact the on the ERT profile, the high-resistivity sands were separated from the Jurassic rocks of the core of the anticline, while on the VES profile, the Jurassic rocks show similar resistivity values to the sands. Due to this fact, these lithological complexes could not be separated on the VES profile.

The analysis of the semi-detailed gravimetric photograph on the surveyed area applied to a number of structural information. It enabled the interpretation of the courses of fold structures and identify the directions of main faults. The analysis also showed significant variation in the density of rocks comprising the Kraśnik sheet area. It should be added that access to as many boreholes as possible is required for reliable interpretation of the gravimetric data. Unfortunately, the semi-detailed photograph does not seem to be sufficient 
for more precise tracking of rocks density in the scale of 1:50,000. It would be advisable to use the detailed gravimetric photograph for more precise determinations. The ALS numerical terrain model also proved to be useful for the geomorphological and geological interpretation of the topography of the areas largely covered by dense vegetation and forests. For this type of areas, aviation photography is not particularly useful.

Geophysical tests accompanied by the analysis of the ALS numerical model should be used comprehensively, in particularly selected ranges, as the information provided by different methods is complementary. The seismic, GPR, magnetic and conductometric methods could provide useful information for geophysical surveys applied to identify geological structures. Whereas, in the case of photogrammetric methods, the digital analysis of archival aviation photographs on photogrammetric stations should reinforce the results of studies, together with the application of ground-based laser scanning.

\section{Conclusions}

1. The ALS DTM method, electrical resistivity methods and the gravimetric method proved useful in the identification and interpretation of the geological structure of the Kraśnik region in the Lublin Upland.

2. The results of surveys enabled the identification of four anticlines and three synclines. The spatial distribution of the faults network was interpreted based on the archival geological data and the analysis of density differences in residual anomalies. Three directions were identified. In the southern part of the sheet, the dominant directions are $\mathrm{N}-\mathrm{S}$ and W-E, while in the northern part, the most common directions are NE-SW and NW-SE.

3. The advantage of the gravimetric method is the possibility of spatial tracking of the distribution of geological structures, e.g. fold structures. This method enables the identification of fault zones which are often covered by overlaying younger formations (e.g. Quaternary).

4. The core of the anticline surrounded by rocks with lower resistivity values on both sides was interpreted from the distribution of resistivity values obtained by the VES method. The shape of the anticline is asymmetric. It is cut with numerous faults which correlate with the faults interpreted from the gravimetric data.

5. The ERT profile shows high-resistivity Quaternary formations which are deposited unconformably on Jurassic and Cretaceous formations. In the NE part of the profile, the interpretation shows sandy loess on loam sands. Loam sands transform into highresistance sands with the values reaching almost $900 \mathrm{ohm}$. The maximum thickness of these sands is approx. $28 \mathrm{~m}$. The entire surface of the roof of the anticline is heavily eroded. This is evidenced by the significant differences in the elevations of the roof surface for over-Quaternary formations.

6. In ERT imaging, the adopted measurement step - 10, 5 or $2 \mathrm{~m}$ - enabled tracking small geological structures which were not visible due to the large distances between consecutive VES soundings.

7. The lithological lines of Jurassic limestone outcrops cut with two fault networks were interpreted on the ALS digital terrain model. The direction of the first system is SW-NE and of the second - SE-NW. Side wings of the anticline are not readable in the topography due to being covered with Quaternary deposits.

8. Further work will be based on combining geological and geophysical data. As a result, three-dimensional geological models will be created. 


\section{References}

1. T.L. Webster, J. Brendan Murphy, J.C. Gosse, I. Spooner, Can. J. Remote Sens, 2, 32, 173-193 (2006) doi: 10.5589/m06-017

2. M.H. Derron, M. Jaboyedof, Nat. Hazard Earth Sys. Sci. 9, 10, 1877-1879 (2010) doi: 10.5194/nhess-10-1877-2010

3. M. Kamiński, Zastosowanie lotniczego skaningu laserowego $i$ tomografii elektrooporowej $w$ kompleksowych badaniach osuwisk: przyktad z Pogórza Dynowskiego (Karpaty zewnętrzne), Przegląd Geologiczny, 63, 410-417 (2015)

4. Z. Fajklewicz, Grawimetria stosowana (Wyd. AGH, Kraków 2007)

5. J. Kondracki, Geografia regionalna Polski (PWN, Warszawa 2002)

6. A.M. Żelichowski., Obszar Radomsko-Lubelski, [w:] Budowa geologiczna Polski, IV, Tektonika, cz. I (Państwowy Instytut Geologiczny, Warszawa 1974)

7. R. Griffin, Atlas grawimetryczny Polski (Państwowy Instytut Geologiczny, Warszawa 1949)

8. P. Krzywiec, W. Morawski., J. Twarogowski, Zastosowanie metod meofizycznych dobadań osadów kenozoicznych $i$ zaburzeń glacitektonicznych na przykładzie potudniowej Warmii, Prace Państwowego Instytutu Geologicznego CLXXXI, 13 - 36 (2004)

9. M.H Loke, RES2DINV, rapid $2 D$ resistivity and IP inversion using least-squares methods. User manual, advanced Geosciences (Inc., Austin 1998)

10. M.H. Loke, Tutorial: 2-D and 3-D electrical imaging surveys (GeoTomo Software Ltd. 2012)

11. Z. Kurczyński, Fotogrametria (PWN, Warszawa 2014)

12. Cz. Królikowski, Z. Petecki, Atlas grawimetryczny Polski (PIG, Warszawa 1995)

13. O. Rosowiecka, Cz. Królikowski, K. Sobień, M. Gołębiewski, K. Lisowski, Opracowanie modelu rozkładu gęstości głównych jednostek geologicznych kraju (PIGNAG, Warszawa 2011)

14. K. Krassowska, Kreda w okolicy Kraśnika - Zakrzewa rena podstawie głębokich otworów wiertniczych), Przegląd Geologiczny 2, 25, 65-70 (1977)

15. K. Wyrwicka, Stratygrafia, facje i tektonika mastrychtu zachodniej części Wyżyny Lubelskiej, Kwartalnik Geologiczny 4, 24, 805-819 (1980)

16. J. Znosko, Atlas Tektoniczny Polski (Państwowy Instytut Geologiczny, Warszawa, 1998) 